\title{
Crimmigration and Refugees: Bridging Visas, Criminal Cancellations and 'Living in the Community' as Punishment and Deterrence
}

Anthea $\operatorname{Vog} 1^{1}$

\section{Introduction}

Australia's status as the only state with a policy of mandatory indefinite detention of all unlawful noncitizens, including asylum seekers, who are within Australian territory is a fact that is both well-known and frequently cited. From its inception, mandatory immigration detention was touted as 'the method of deterrence for those seeking asylum onshore' and since then 'mandatory detention has been at the forefront of a deterrence as control and control as deterrence discourse' ${ }^{2}$. The imagined subjects of deterrence are frequently asylum seekers presented as 'bogus' or as economic migrants, and the sites for control are Australia's 'immigration program' and borders. While these dual factors have animated the implementation and continuation of the policy for over 25 years, the contemporary practice and enforcement of detention in Australia presents a much more complex picture.

While no sitting Australian Government has publicly resiled from the mandatory indefinite detention of all 'unlawful non-citizens' as they are classed in the legislation, the application of a mandatory detention policy to people deemed unlawful - and in particular asylum seekers who arrive without authorisation $^{3}$ - has, for some time, been in major decline. In this chapter I explore shifts in the practices of onshore detention to argue that the mandatory detention of asylum seekers must be read alongside and in light of Australia's bridging visa regime, and in particular the large number of asylum seekers released from detention and living in the Australian community on discretionary and short-term bridging visas. In general, bridging visas serve to temporarily regularise the legal status of people awaiting the resolution of a visa application, and for unlawful non-citizens they may allow for release from otherwise mandatory detention. Using crimmigration as a framework, this chapter argues that Australia's bridging visa regime should not be analysed as a practice ancillary to the primary policy of mandatory detention, but as central to the logic and policy of punishment and deterrence of onshore asylum seekers seeking protection within Australian territory. The use of temporary bridging visas to release asylum seekers from detention is now central to the punishment and deterrence of unauthorised refugee arrivals.

In analysing the bridging visa regime, the chapter focusses in particular on the growing use of broad visa cancellation powers against asylum seeker bridging visa holders. It addresses cancellation on both criminality grounds (including on the basis of criminal charges alone) and under the Asylum Seeker Code of Behaviour ('the Code'), ${ }^{4}$ and analyses data accessed via Freedom of Information (FOI) requests that chart the use of the cancellation powers from 2014-2016. The bridging visa cancellation powers and policing of the Code constitute textbook examples of crimmigration practice, where criminal law and immigration law operate under conditions of 'interchangeability and mutual enforcement'. Criminal law is used against Bridging Visa Class E (BVE) holders to punish, to enforce racialised

\footnotetext{
${ }^{1}$ Lecturer, Faculty of Law, University of Technology Sydney.

${ }^{2}$ Pickering and Lambert 2002, p. 78 (emphasis in original).

${ }^{3}$ Migration Act 1958 (Cth) ss 14, 189.

${ }^{4}$ Migration Act 1958 (Cth) s 116; Department of Immigration and Border Protection (2013).

${ }^{5}$ Aas 2014, p. 525.
} 
immigration controls and to make asylum seekers deportable, ${ }^{6}$ just as immigration detention and deportation are justified as crime reduction strategies. ${ }^{7}$

In analysing the use of the cancellation powers and the FOI data, the chapter also argues that as the result of visa cancellation on criminal and behavioural grounds asylum seekers are increasingly being excluded and punished in ways that are increasingly similar to criminalisation of the broader population of migrants and 'non-citizens'. For the approximately 19,500 asylum seekers classified as 'unauthorised maritime arrivals' currently living on BVEs, the use of bridging visa cancellation powers demonstrates that asylum seekers in Australia are increasingly subject to policing and control associated with the regulation via the 'internal' border - practices of exclusion traditionally exercised against racialised non-citizen populations who are not asylum seekers or the subject of (mandatory) indefinite detention - as well as crude 'external' border controls. ${ }^{8}$ That is, it is not only asylum seeker BVE holders' mode of entry that is criminalised, but increasingly, criminal law and behavioural regulations are being used to punish and deter BVE holders while they are in the community, at the same time as the threat of redetention on almost any ground is preserved. For BVE holders, both the internal and external border are at play. At the same time, criminal cancellation powers are being used in concert with the systematic economic marginalisation of asylum seeker bridging visa holders, achieved via visa conditions limiting access to work and welfare, which have to date been the primary means employed by Australian Governments to punish and control bridging visa populations.

In developing the above claims, Part I of the chapter traces several reforms to onshore mandatory detention, or more accurately, to the practice of temporary release of onshore asylum seekers from detention, which have taken place as the legal framework of mandatory indefinite detention has been maintained. Part II shifts to focus on practices of bridging visa cancellation, and the policing and surveillance of BVE holders. I then analyse recent data regarding BVE visa cancellation and enforcement of the Code of Behaviour, across 499 alleged breaches of the criminal law or Code from June 2014 to July 2016.

The regulation of BVE holders using the Code and criminal law demonstrates how the regulation of non-citizens at the intersection of criminal and immigration law significantly exceeds each separate area of regulation and law. As Bosworth and Guild have traced, the use of criminal law powers against noncitizens is not simply an example of 'governance through crime'. ${ }^{9}$ Migration management and criminalisation exceed national and criminological accounts of law and order politics, to include 'new' crimes and modes of criminalisation 'located on or beyond the border', which 'arise from and reformulate understandings of identity, community and justice'. ${ }^{10}$ That is, crimmigration and its management of racialized, non-citizen populations, while continuous with many past practices of racialized punishment and border control, is a unique practice with its own structure and logic. In this vein, the chapter reinforces Vázquez's argument that, despite a history of interaction between race, crime and citizenship (in the US specifically) that long pre-dates crimmigration scholarship, the

\footnotetext{
${ }^{6}$ See De Genova, 2002.

${ }^{7}$ See Aas 2014, pp. 25-26. As explained in the next section, BVE is a category of bridging visa available to applicants identified as unlawful non-citizens, including asylum seekers classified as 'unauthorised maritime arrivals'; see Migration Regulations 1994 (Cth) sch 2 sub-cls 050, 051.

${ }^{8}$ See Weber 2013.

${ }^{9}$ See Garland 2003.

${ }^{10}$ Bosworth and Guild 2008, p. 704.
} 
multiple dimensions, purposes and impacts of contemporary crimmigration have their own institutional structures, which are only beginning to emerge. ${ }^{11}$

Before addressing the shifts in enforcement of detention against onshore asylum seekers, it is important to note that the decline in detention rates for onshore refugee arrivals is also a result of the aggressive externalisation of Australia's deterrence policies, via both Australia's militarised boat interception and turn-back policy, and what is known as offshore detention. That is, the establishment of Australianfunded prison camps for refugees and asylum seekers in Nauru and Papua New Guinea. Indeed, the policing of Australia's naval border has all but prevented asylum seekers from arriving in Australian territory. ${ }^{12}$ And, at the same time as the population of detained asylum seekers on the Australian mainland has decreased, the number of non-citizens being held in Australian detention centres due to visa cancellations on criminal grounds or the failure of a statutory 'character' test has been steadily increasing. As the Australian Department of Home Affairs itself reports, '[b]etween the 2013-14 and 2016-17 ... the number of visa cancellations on character grounds have increased by over 1400 per cent'. ${ }^{13}$ As at 2018, non-citizens whose visas have been cancelled on character grounds comprised the single largest population in Australian immigration detention. ${ }^{14}$ This issue is addressed in Billings and Hoang's chapter in this collection.

\section{Detention and Release}

While the focus of this chapter is on the use of Bridging Visa Class E, Australian immigration law provides for a range of bridging visas. These visas serve to regularise the legal status of people awaiting the resolution of their immigration matters, which is achieved either via the grant of a valid visa or departure or deportation from Australian territory. In Australia, a BVE is available to certain noncitizens who are either applying for a substantive visa or making arrangements to leave Australia and they allow BVE-holders either to avoid mandatory detention or to be released from immigration detention. There are two classes of BVE being a 'general' and a 'protection visa' class (050 and 051). Both categories of BVE are for people who are identified as unlawful non-citizens, including asylum seekers classified as 'unauthorised maritime arrivals'.

Those investigating crimmigration and the architecture of migration and border control have long highlighted the penality of immigration detention. Immigration detention is necessarily situated within 'specific practices of policing and carceral geographies'. ${ }^{15}$ This is the case not least because:

'Interior enforcement' cannot happen in the United States, Australia, and the European Union without capacities for surveillance and apprehension delegated to local authorities; nor can detention happen in the absence of existing jails. Imprisonment and detention involve similar processes of racialized entrapment, together generate economic vulnerability (and gain), and increasingly share sturdy legal and discursive practices of racialized criminalization. ${ }^{16}$

\footnotetext{
${ }^{11}$ Vázquez 2015; see also Kaldelfos and Finnane; Gerrard and Boon-Kuo in this collection. Vázquez draws on work that reads crimmigration as a backlash against civil rights, and argues that '[i]n a continued attempt to limit the number of nonwhite individuals who entered and remained in the United States, the immigration system began to use criminal status as a proxy for race'; she also writes that 'crimmigration must be defined as a portmanteau, an institutional structure in which criminal and immigration law have merged in various ways to create a singular and distinct concept with its own structure of laws, procedures and practices.' Vázquez 2015, p. 607; McElrath et al 2014. On the often ignored continuities between current detention practices and histories of race, social control and detention in Australia, see Nethery 2012.

${ }^{12}$ In early 2017, the Government 'celebrated' 1000 days of no asylum boat arrivals and the successful interception and return of 30 boats and 765 people attempting 'illegal' entry; see Dutton 2017.

${ }^{13}$ Department of Home Affairs 2018.

${ }^{14}$ Refugee Council of Australia 2018a.

15 Mountz et al. 2012.

${ }^{16}$ Mountz et al. 2012; see also Martin and Mitchelson 2009.
} 
Scholarship at the intersection of immigration control, criminal law and policing has, at the same time, examined the modes of racialised confinement of non-citizens outside of the physical sites of detention centres and prisons, in symbolic and actual spaces of 'suspension and liminality, where detainees or non-citizens are expected to "wait out" their status regularisations' in the absence of direct imprisonment. ${ }^{17}$

Gaps between detention policy and practice in Australia, and between detention as law and discretionary release from detention, are central to understanding detention as a 'core idea of migration control'. ${ }^{18}$ For a significant period, mandatory indefinite detention has been the cornerstone of successive Australian Governments' management of onshore refugees in both policy and practice. While it is not my intention to fully trace shifts in detention practices here, I nonetheless highlight several reforms to onshore detention and practices of temporary release of onshore asylum seekers from detention on BVEs. Critically, the shifts in onshore detention practice have mainly been achieved through policy change or the expanded exercise of existing discretions, rather than formal law reform. As a consequence, there is an ever-widening gap between the law of mandatory indefinite detention and the reality of regulating onshore asylum seekers, which is increasingly undertaken outside of imprisonment in closed detention centres.

The disjuncture between government policy and government practice leads to confusing statements such as the following one currently on the Department of Home Affairs website:

A person who does not hold a valid visa must be detained under the Migration Act 1958, however whether the person is placed in an immigration detention facility is determined using a risk-based approach. ${ }^{19}$

The Department goes on to declare that while 'the surge in illegal maritime arrivals saw the detention population peak at [around] 10,000 in July 2013', under the current Government, 'the reduction in boat arrivals over the past three years has seen the number of people in detention fall to around 1500 and has allowed the Government to close 17 immigration detention facilities by the end of $2018^{\prime} .^{20}$ The Department also highlights that 'illegal maritime arrivals' (IMAs) only make up about one third of the detention population, and that as the population of so-called IMAs in detention has dropped, the number of people in immigration detention 'whose visa has been cancelled based on character grounds' has grown. ${ }^{21}$ Unsurprisingly, the Department does not explain the overlap between the categories and that certain IMAs have been re-detained under criminal cancellation powers, most likely because one of the discursive aims of the explainer is to highlight that the Government has 'stopped the boats' and reduced the number of people arriving 'illegally' to seek refugee protection.

Up until at least 2008, there were limited exceptions to the mandatory and indefinite detention of asylum seekers arriving in Australia without authorisation. The routine and indefinite detention of onshore asylum seekers was foregrounded as a key mode of both deterrence and border control. As Billings has tracked, discretionary powers, which permitted release of asylum seekers from detention in limited

\footnotetext{
${ }^{17}$ Silverman and Massa 2012, p. 679.

18 Silverman and Nethery 2015, p. 2.

${ }^{19}$ Department of Home Affairs n.d.

${ }^{20}$ Department of Home Affairs n.d.

${ }^{21}$ Department of Home Affairs n.d. Note, the conservative Liberal Government uses the terminology of 'illegal maritime arrival' as a matter of policy even though the statutory language is 'unauthorised maritime arrival' as described above. The rhetoric of illegality is of course contested, and is used to criminalise those entering without a valid immigration status.
} 
circumstances, were seldom used due to a 'risk-averse and security-focused culture within the Immigration Department'. ${ }^{22}$ Indeed, this was the case in spite of legislative changes which took place in 2005, giving the Minister of Immigration a non-compellable, discretionary and personal power to release immigration detainees from detention through the grant of a visa, where the Minister holds that it is 'in the public interest to do so' ${ }^{23}$ Under these reforms, the Minister may issue a visa independently or on application. ${ }^{24}$ However, for 'unauthorised maritime arrivals' a visa application cannot be made due to a blanket statutory bar on visa applications by asylum seekers arriving by boat. This bar may only be lifted at the discretion the Minister. ${ }^{25}$

The 2005 reforms also introduced the option of residential housing or community detention of asylum seekers, primarily intended for women and families with children. ${ }^{26}$ These reforms, which 'preserved the broad framework of mandatory detention but gave it a "softer" edge', ${ }^{27}$ were in part a response to the indefinite, protracted detention of stateless detainees and to public revelations that permanent Australian residents, including Cornelia Rau and Vivian Alvarez Solon, had been unlawfully detained. ${ }^{28}$ While the 'public interest' power was also used to release some highly vulnerable detainees, the power was primarily used to place women, children and families in community detention.

The more significant, albeit still discretionary, shift in onshore detention policy and practice was introduced as consequence of electoral reforms promised by the Australian Labor Party, which were partially introduced after they came into government in 2008. As Billings records:

In 2008, the Labor Government championed a new beginning to immigration detention, signalling a move away from a presumption of secure detention to a presumption that unlawful non-citizens in Australia will remain in the community pending resolution of their status. This 'risk-based' policy framework was infused by values that were more consistent with international human rights standards safeguarding the right to liberty. Under the policy, detention [was] to be used in limited circumstances and for the shortest period possible. Officially, unlawful non-citizens are initially detained for administrative reasons: health, identity, and security checks. ${ }^{29}$

Despite the then Labor Government's promises that law reform would take place, the reforms were not formalised and the Government failed to comply with its own policies of only risk-based and short-term detention. ${ }^{30}$ However, in November 2011, the then Labor Government formally announced that following health, security and identity checks, selected 'irregular maritime arrivals' would be placed into the community with work rights while their asylum claims were assessed. ${ }^{31}$ It was from this

22 Billings 2015, p. 1390.

${ }^{23}$ Migration Act 1958 (Cth) s 195A.

${ }^{24}$ Migration Act 1958 (Cth) s 195A.

${ }^{25}$ Migration Act 1958 (Cth) s 46A. Under the Migration Act, any person detained as an unlawful non-citizen must be informed of the right to apply for a visa, including a bridging visa, as soon as reasonably practicable after they are detained. $\square$ Only applications for a protection visa or a bridging visa are not subject to a strict two or seven day time limit for the making of an application once detained; see Migration Act 1958 (Cth) ss 194-195.

${ }^{26}$ Migration Amendment (Detention Arrangements) Act 2005 (Cth); see also Opeskin 2012. The reforms also made new provision for the oversight of the Commonwealth Ombudsman in cases where persons had been in detention for over two years.

27 Opeskin 2012.

${ }^{28}$ Grewcock 2005.

${ }^{29}$ Billings 2015, p. 1391 (footnotes omitted).

${ }^{30}$ Billings 2015, p. 1391.

${ }^{31}$ These principles are set out in the Department's policy guideline, which was announced in 2008 and still guides release from detention. As opposed to mandatory detention of all non-citizens, the policy establishes that three main groups will be subject to detention. All unauthorised arrivals for management of 'health, security and identity' risks; unlawful non-citizens who present an 'unacceptable risk' to the community and unlawful non-citizens who have breached previous visa conditions. 
point onwards that large numbers of asylum seekers classified as unauthorised maritime arrivals were released on BVEs, with the Government 'expecting' that '100 IMAs' would be released each month. ${ }^{32}$ Consequently, from 25 November 2011 to 30 June 2012, 2,731 BVEs were granted to unauthorised maritime arrivals, and two years later, at 30 June 2014 , this number had risen to $29,564 .{ }^{33}$ By 30 September 2016, 35,834 BVEs had been granted to asylum seekers classed as unauthorised maritime arrivals. ${ }^{34}$ Notably, at the same time as making the announcement in 2011, then Immigration Minister Chris Bowen confirmed the Government remained 'committed to maintaining a mandatory detention system, including using mandatory detention on Christmas Island for reception and initial checks'. ${ }^{35}$

Critically, the reestablishment of offshore processing and detention centres also occurred at this time and signalled, amongst other things, the unsustainability of the onshore detention centres given the scale of onshore arrivals, which peaked in $2012 / 13$ at a population of over 10,000 detainees. ${ }^{36}$ The reestablishment of the offshore policy in 2012 was due, in part, to the pressures on the mainland detention network and the Government's struggles to 'maintain a burgeoning detention network on both Christmas Island and the Australian mainland'. ${ }^{37}$ Simultaneously, 'pressures on the immigration detention network' from 2008 to 2013 influenced the Government's decision to allow asylum seekers to 'live in the community on bridging visas and in community detention'. ${ }^{38}$

In this period, immigration detainees - who were still at the heart of the Government's deterrence rhetoric - were released into the community in significant numbers, while a select population of asylum seekers were transferred to closed detention camps on Manus Island and Nauru to send a message that there was 'no way' boat arrivals would ever settle in Australia. ${ }^{39}$ Indeed, attention to the proportion of asylum seekers transferred to Nauru and Manus Island highlights the profoundly and cruelly arbitrary nature of the offshore camps. Even at their peak in mid-2014, the offshore detention centres housed approximately 2,450 asylum seekers and refugees, out of a population of 30,500 'eligible' for transfer. ${ }^{40}$ The camps were intended to exist at the centre of the policy objective of deterrence, at the same time as large numbers of asylum seekers were released into the Australian community and subject to social, economic and administrative regimes of exclusion to ensure they had 'no advantage' over those who had waited their turn and not sought asylum by boat. ${ }^{41}$

Although I have not addressed the cost and profits associated with detention, before examining the release and regulation of the BVE population as a form of crimmigration control it is worth noting that financial cost cannot adequately explain shifts in onshore detention practice. The Australian Government has repeatedly demonstrated that there is no price too high for the implementation of its border control and deterrence policies. Indeed, what Grewcock has described as 'the unrelenting mobilisation of state resources to prevent the free movement of refugees in the region', ${ }^{42}$ is a fact that

These together comprise one of the seven key 'immigration detention values'. Another sets out that 'Detention in immigration detention centres is only to be used as a last resort and for the shortest practicable time'; see Department of Immigration and Border Protection (n.d.), chapter 1.

${ }^{32}$ Bowen 2011.

${ }^{33}$ Phillips 2017, p. 4.

${ }^{34}$ Phillips 2017, p. 4.

${ }^{35}$ Bowen 2011.

${ }^{36}$ Between 13 August 2012 and 24 May 2013 19,048 people arrived by boat; see Grewcock 2014, p. 73.

${ }^{37}$ Grewcock 2014, p. 73.

${ }^{38}$ Koleth 2012.

${ }^{39}$ Laughland 2014.

${ }^{40}$ Karlsen 2016.

${ }^{41}$ Cohen 2013.

42 Grewcock 2014, p. 77. 
has been welcomed and accommodated by private contractors who reap the 'profits' of these policies and expand their services accordingly. ${ }^{43}$ The relentless privatization of 'detention services' has gone hand in hand with the growth of the number of detained migrants. The creation of 'additional capacity' in detention centres simultaneously entrenches an economic motive and outcome for each contract (and extra bed) filled. ${ }^{44}$ This is clearly demonstrated by the expansion of immigration prisons and detention centres offshore and in other jurisdictions.

\section{Bridging Visas, Cancellation Powers and Crimmigration}

Crimmigration as a method highlights how asylum seekers become 'ensnared in a stringent mesh of administrative, criminal and immigration laws' ${ }^{45}$ Gerard and Vecchio have analysed how these different forms of regulation, law and policy work in concert to 'entrap' asylum seekers, both in the physical confinement sense and also in the criminal legal sense by creating conditions that lead to breaches of existing criminal laws. ${ }^{46}$ They argue that these 'entrapping' practices and regulatory frameworks not only impose conditions on and constrain asylum seeker movement and behaviour, but are themselves criminogenic. ${ }^{47}$ BVEs certainly cause 'vulnerability and a daily lived experience that itself is criminogenic ${ }^{48}$ and, through the production of crime and criminalised behaviour (and deviance), objectives of both deterrence and punishment are met. Despite this, it is also clear that BVEs holders continue to find ways to negotiate visa restrictions and make their lives liveable to the greatest extent possible under the immense emotional, social, economic and personal impact of BVEs and attached conditions. ${ }^{49}$

Unlike mandatory indefinite detention in the past, and 'offshore' processing in the present, the scale of release, regulation and punishment of asylum seekers on bridging visas has not (at least until recently) been at the centre of scripts about deterrence and the criminalisation of asylum seekers in Australia. ${ }^{50}$ Despite the quiet and opaque grants of BVEs through discretionary processes, often obscured behind walls of bureaucracy, ${ }^{51}$ important and ongoing work has documented the harms of bridging visas, and the impossibly restrictive conditions attached to them. The denial of the rights to work and access to welfare support (the 'no work, no income, no Medicare' trifecta) has amounted to enforced poverty for certain bridging visa holders. ${ }^{52}$ The conditions attached to BVEs have been analysed as a form of deportation by destitution, and more recently, as 'starving out' asylum seekers, ${ }^{53}$ or, as Hekmat has written, as weaponising food in order to pressure asylum seekers to leave. ${ }^{54}$ This strategy was more or less made explicit in the 2018 announcement (yet to be fully implemented) that income support for all

\footnotetext{
${ }^{43}$ Grewcock 2014, p. 77.

${ }^{44}$ Mountz et al 2012; see also Sudbury 2005.

${ }^{45}$ Vecchio and Gerard 2018.

${ }^{46}$ Vecchio and Gerard 2018, p. 5.

${ }^{47}$ Vecchio and Gerard 2018, p. 5.

48 Vecchio and Gerard 2018, p. 5.

${ }^{49}$ Hartley and Fleay 2017. As Vecchio and Gerard describe this elsewhere, the 'social, legal and economic processes underpinning precarity' generate the boundaries in which an individual's existence and agency are possible; see Vecchio and Gerard 2018, p. 13.

${ }^{50}$ Pickering and Weber 2014.

${ }^{51}$ Welch 2012.

52 Markus and Taylor 2006. Markus and Taylor also note the extreme complexity of how and when conditions attach, making the visa class itself a strategy, with the complexity further marginalising those attempting to live on BVEs.

${ }^{53}$ Refugee Council of Australia 2018b.

${ }^{54}$ Hekmat 2018.
} 
BVE holders with work rights will be withdrawn, regardless of whether those affected by the changes actually have a current job or access to work. ${ }^{55}$

Immense precarity and socio-economic vulnerability have become the trademarks of the temporary BVE for asylum seekers. ${ }^{56}$ These punitive conditions are exacerbated by the prolonged periods for which asylum seekers hold BVEs due to lengthy delays in the resolution of protection visa applications. For asylum seekers on BVEs, the denial of access to a subsistence level of income, to work rights (often simultaneously), and medical services are tactics that have been repeatedly documented to cause irreparable mental distress and harm. Hekmat has documented that more than 10 asylum seekers on bridging visas have committed suicide in the four years to April 2018. ${ }^{57}$. These visas are all too clear examples of how time (or specifically temporariness) and socio-economic restrictions are used as technologies of punishment. ${ }^{58}$ Not least among the harms of BVEs is the often short period of validity of each $\mathrm{BE}$ and the need to regularly seek entirely discretionary renewals.

Due to the discretion governing the grant of BVEs and the short amount of time between renewals, to be released on a BVE is to live with the constant possibility of re-detention. Boon-Kuo, in analysing the discretion and conditionality that governs BVEs, describes the visa as an example of the state mobilising a 'legal status as a mechanism of selective and arbitrary control' ${ }^{59}$ such that 'it is not legal status itself that is important for release from detention', but the conditions imposed on that status. ${ }^{60}$ As well, McNevin, Correa Velez and Boon-Kuo have demonstrated how BVEs, and the conditions attached to them, have created relationships of dependence and/or surveillance not just with Government but with refugee NGOs and settlement agencies contracted by Government to provide limited or diminished welfare and medical support, and co-opted and corralled into community policing and surveillance. ${ }^{61}$ This issue is plainly evidenced in the FOI data explored below.

The increased use of visa cancellation powers against BVE holders, the heightened surveillance of this population, and the use of these mechanisms alongside systematic denials of access to work and income together articulate the diverse mechanisms used, in Vecchio and Gerard's words, to 'entrap' asylum seekers. The introduction of the Asylum Seeker Code of Behaviour, which I discuss below, has also drastically increased both the fact and fear of surveillance, and with it the threat of re-incarceration and diminished capacity for agency and resistance. Examining both the Code of Behaviour and cancellation powers brings the use of the criminal law as an old and new method of immigration control and punishment back into focus in reference to asylum seekers on bridging visas. The focus on criminal cancellation provisions and behavioural surveillance operates alongside already criminogenic conditions of socio-economic precarity attached to bridging visas.

\subsection{Bridging Visa Cancellation Powers: Criminality Grounds and the Asylum Seeker Code of Behaviour}

As described above, work charting the negative impact of the BVE framework to BVE holders has frequently highlighted the social and economic harms of this visa category - alongside the temporary

\footnotetext{
${ }^{55}$ Refugee Council of Australia 2018c.

56 Boon-Kuo 2017, p. 113.

${ }^{57}$ Hekmat 2018.

${ }^{58}$ Pickering and Lambert 2002.

59 Boon-Kuo 2017, p. 113.

${ }^{60}$ Boon-Kuo 2017, p. 123.

${ }^{61}$ Boon-Kuo 2017, p. 113.
} 
nature of these visas - as the core methods of punishment and deterrence. The use of criminal and behavioural grounds for discretionary cancellation of BVEs not only warrants further investigation, but also demonstrates the adaptability of crimmigration strategies and, as argued here, bridging visas as core to the deterrence of refugee arrivals. Asylum seekers (whose immigration and movement has already been 'criminalised') are now also subject to the use of much more classic criminal law processes and powers against them, in a manner associated with populations of non-asylum seeker, non-citizens. To examine this issue more closely, the remainder of this chapter addresses bridging visa cancellation powers and the exercise of these powers against BVE holders using data acquired from the Department of Border Protection (as it then was) in late 2016.

Alongside the wide-ranging visa cancellation powers in the Migration Act 1958 (Cth) ('the Act'), including the well-known character cancellation provisions under section 501 of the Act, there are additional and expansive grounds for the cancellation of visas under section 116. Section 116, which can only be used to cancel temporary visas if the visa-holder is in the Australian migration zone and is immigration cleared, ${ }^{62}$ is the power under which the majority of asylum seekers' BVEs have been cancelled. Section $116(\mathrm{~g})$ of the Act sets out that a visa may be cancelled if a prescribed ground for cancelling a visa applies to the holder. Regulation 2.43 prescribes these grounds, and provides that the Minister may cancel a Subclass 050 (Bridging [General]) visa or a Subclass 051 (Bridging [Protection Visa Application]) if the Minister is satisfied that the holder has been convicted of an offence against a law of the Commonwealth, a State, a Territory or another country; or if the Minister is satisfied the holder has been charged (but not convicted) with an offence against a law of the Commonwealth, a State, a Territory or another country. ${ }^{63}$

These powers came in to effect in June 2013, when the Labor Government expanded Ministerial powers to cancel Subclass 050 and 051 visas where the visa holder was under investigation of, convicted of, or charged with, a criminal offence. ${ }^{64}$ The amendment was repeatedly justified on the nebulous grounds of ensuring the 'safety of the Australian community', with then Immigration Minister, Brendan O'Connor, stating that '[ $t]$ he Government has become increasingly concerned about unauthorised arrivals who engage in criminal conduct after being released into the community on BVEs while they await for the claims to be assessed' ${ }^{65}$ No specific reasons were given to justify the Government's 'increased' concern about this population. Nor did the Government differentiate between the threat posed to the community by minor offences, such as traffic infringements or minor damage to property, and major offences, such as aggravated or sexual assault.

The cancellation of BVEs under s 116(g) of the Act has been the subject of a 2016 Commonwealth Ombudsman Report. The investigation was conducted as an own motion initiative of the Ombudsman, after the Ombudsman received complaints relating to a cohort of people whose bridging visas had been cancelled 'on the basis of a criminal charge, conviction, or the possibility that the person poses a threat to the Australian community', ${ }^{66}$ a number of whom remained in detention long after criminal charges had been dropped or after having been found not guilty of the relevant charge. The report sharply criticised the administration of people in immigration detention who have had their BVE cancelled

\footnotetext{
${ }^{62}$ Migration Act 1958 (Cth) s 117.

${ }^{63}$ Migration Regulations 1994 (Cth), reg 2.43. The subsection also allows for cancellation in circumstances where an Interpol notice has been issued.

${ }^{64}$ The Government also introduced a new condition that could be attached to subclass 050 and 051 visas, requiring that a visa-holder not engage in criminal conduct.

${ }^{65}$ Migration Amendment (Subclass 050 and Subclass 051 Visas) Regulation 2013 (Cth) Explanatory Statement.

${ }^{66}$ Neave 2016, p. 1.
} 
based on their commission, or suspected commission, of a crime ${ }^{67}$ It also criticised the manner in which section $116(\mathrm{~g})$ and accompanying regulations reverse the presumption of innocence for bridging visaholders, who may be detained if charged with rather than found guilty of a crime. In appraising the data below, this fundamental aspect of the bridging visa regime and its ousting of one of the criminal law's most basic protections, must frame crimmigration analyses of visa cancellations under the Act.

The other key component of bridging visa cancellation powers for asylum seekers is the Asylum Seeker Code of Behaviour, introduced by the Liberal-National Coalition Government in December 2013. The Code, which enlarges the already vast discretions relating to bridging visa cancellation, applies to all so-called 'unauthorised maritime arrivals' (UMA) who apply for or seek to renew a bridging visa. ${ }^{68}$ In order to access a bridging visa, this group of asylum seekers must sign the Code, and are thereafter bound by a 'list of expectations' about how to behave at all times while in Australia - expectations which range from obeying the law to refraining from spreading rumours, spitting or swearing in public, engaging in 'disruptive activities' or persistently irritating anyone. Signing and adhering to the Code is a precondition for an UMA either to be released from detention or to remain in the community.

Data released by the Department sets out that, as at June 2016, 57,430 BVEs had been granted to asylum seekers who had signed the Code, which includes 54,235 BVE renewals. As I have noted with Methven elsewhere, in its first years of implementation there was very limited use or enforcement of the Code, even as it had an immense impact on the BVE holders subject to its vast and undefined prohibitions. The Department did not report on the number of cancellations in the Code's first year. ${ }^{69}$ In $2015-16$ the Department reported that 281 BVE holders had been alleged to breach the Code, but that no cancellations were made. ${ }^{70}$

Often when the criminalisation of asylum seekers is discussed in Australia, this is a reference to the criminalisation of 'unlawful' or 'unauthorised' arrival; that is, the criminalisation of immigration status or immigration breaches. As Gerard and Pickering explain, 'construction of refugees and migrants as "criminal" makes the application of criminal justice responses to irregular migration seem appropriate'. ${ }^{71}$ Refugees who arrive unlawfully are not only made 'illegal' but they are illegals; and, like 'domestic' law breakers, they are constructed as dangerous, undeserving and deviant. ${ }^{72}$ While refugees and asylum seekers have been classified as illegal, they have not been at the centre of Australian Government's rhetoric about 'criminal' migrants. This is what Bosworth and Guild identify as the expansion of 'governance through crime' to migration governance through crime. ${ }^{73}$ The final section of this chapter describes a shift towards the 'criminalisation' of this population using the criminal law as such, and the Code of Behaviour as a proxy for the criminal law, rather than breaches of migration law.

\subsection{Data and Analysis}

\footnotetext{
${ }^{67}$ Neave 2016.

${ }^{68}$ See Department of Immigration and Border Protection 2013.

${ }^{69}$ Department of Immigration and Border Protection 2014.

70 Department of Immigration and Border Protection 2016. In 2014-15, one BVE holder had their visa cancelled due to a breach of the code and 49 people were referred to service providers or Department officers to reinforce the operation of the Code. Some referrals were made for counselling in light of the breach or for vaguely defined 'discussions' with SRSS (Status Resolution Support Service) providers; see Department of Immigration and Border Protection 2015, pp. 51-52.

${ }^{71}$ Gerard and Pickering 2013, p. 287; see also Mountz 2010

72 Bosworth 2008, p. 208; Dauvergne 2008.

${ }^{73}$ Bosworth and Guild 2008, p. 704; Garland 2003.
} 
In late 2016, the Department partially fulfilled an FOI request seeking access to the total number of allegations of breaches under the Code; the nature of the alleged breach; a description of behaviour giving rise to the breach; a description of the complainant or reporter; and, the outcome of the allegation including any action taken by the Department where a breach or no breach was found for the period from June 2014 to July 2016. ${ }^{74}$ The Government released a table of 499 breaches and alleged breaches outlining this data, but also included cancellations made under 'non-Code powers', as the Department put it. In this dataset, the primary 'non-Code' cancellation power used was s 116(g), outlined above. This section sets out the content and analysis of this data to explore what it reveals about the use of criminal cancellation powers against asylum seekers living in the community.

It is worth noting from the outset that the data in the table is best described as patchy. The table itself appears to be the Department's primary record of BVE cancellations, filled in inconsistently by (one presumes) multiple Departmental employees. For example, not all columns have been completed for every allegation by the officer, or officers, entering the data. The data is nonetheless valuable. Unlike many available Government records, the table lists outcomes, allegations, and the source of the allegation, even where cancellation did not take place. In line with Boon-Kuo's observations about migration policing generally, the 'front-ending' of discretion and the limited recording of how this discretion is exercised makes it very difficult to know, and therefore analyse, the details of these cases. ${ }^{75}$ However, the table's detailing of information beyond simply where cancellations were made already provides us with a more variegated picture of cancellation practices. It is also worth keeping in mind that the Department refused to disclose the key details of all cases where a cancellation was made for even the Ombudsman's formal review of section $116(\mathrm{~g})$, due to 'resource and computer system limitations' ${ }^{76}$ In this context and atmosphere, attending to this 'top level' data is important.

The data reveals, in no uncertain terms, the regular and increasing use of section $116(\mathrm{~g})$ cancellation powers against BVE holders during the period covered by the FOI. Of the 499 mere allegations of a possible breach recorded, at least 159 , or one in three, allegations resulted in cancellations or nonrenewals of BVEs under non-Code powers, including specifically under section 116(g). The Ministerial Direction guiding the use of this power is currently under review, but at the time of writing set out that 'decision-makers should have regard to the principle that the Australian Government has a low tolerance for criminal behaviour' in ' weighing the Government's view that the prescribed grounds for cancellation at regulation 2.43(1)(p) and (q) should be applied rigorously'. ${ }^{77}$ Based on the dataset it is not possible to gain insight into the approximately $2 / 3$ of mere allegations that did not result in visa cancellation or non-renewal. Notably, in 2016, the Department refused to provide the Ombudsman with any examples of cases in which a decision was taken not to cancel a visa under the regulations after a Notice of Intention to Cancel had been issued, though they reported that decisions not to cancel were 'common'. ${ }^{78}$

In the process of interpreting the 159 allegations (32\%) in the FOI dataset that resulted in BVE cancellations, it is important to give some sense of the nature of the so-called 'allegations'. In 55 instances $(35 \%)$, the table clearly records that cancellation took place on the basis of a criminal charge

\footnotetext{
${ }^{74}$ Note that this FOI request followed on from a previous request, which requested the same information but for the period from the Commencement of the Code till mid-2014.

${ }^{75}$ Boon-Kuo 2017, pp. 29-31.

${ }^{76}$ The Report also noted the differing levels of detail in the case files and decisions that were able to be accessed. In response, the Department accepted that there was 'capability gaps' and a need for better training of officers. As noted in Neave 2016, pp. 5, 9, the Department also acknowledged 'inconsistent record-keeping practices across states or business lines' and 'some variance in the quality of decision records'.

${ }^{77}$ Minister for Immigration and Border Protection 2014.

${ }^{78}$ Neave 2016, p. 21.
} 
rather than conviction. The remaining instances $(65 \%)$ do not directly specify the basis for cancellation. However, since the table at times lists 'fines' or 'sentences of imprisonment' for these instances, a tentative inference is that the many allegations where a criminal sentence is not included, are the subject of criminal charges, not convictions. As noted, the exact statutory provision used for cancellation (outside the use of non-Code powers or section 116(g)) is also not listed in every instance.

The other clear and significant finding from this data is that where a breach of the Code was found, this was most likely to result in a BVE holder being referred for counselling or to 'a discussion' with either with a Department officer or the BVE holder's Status Resolution Support Services (SRSS) provider as the only action in response to the breach. Of the 192 allegations (38\%), where it was found that the BVE holder breached the Code, in only one instance is it clear that the Code breach resulted in a visa cancellation, and in 163 instances $(84 \%)$ a referral for counselling or for a discussion was made. ${ }^{79}$ Read as a whole, it is clear that Code powers are not being used to cancel bridging visas. Overwhelmingly, cancellation powers are being exercised under section $116(\mathrm{~g})$. In a number of instances where the relevant allegation may have been made (and investigation/surveillance takes place) as a result of the Code, cancellation took place under the legislative power. One possible implication here is that the Code is being used to facilitate surveillance, policing and reporting, but that criminality grounds are then being used to cancel the relevant visa rather than the Code itself. As compared to the criminality grounds, where a charge must be laid, the standards of proof and evidence for allegations under the Code are much less straightforward and often rely on third party evidence or witnesses.

In cases recorded by the Ombudsman, even where the AAT had set aside the Department's decision to cancel a visa, asylum seekers remained in detention where the Minister had not intervened to grant a new visa, effectively rendering administrative review entirely ineffectual and irrelevant. This, alongside cases where BVEs were cancelled even though the original criminal charge was dropped, again demonstrates the multiple layers, stages and sites of discretion operating to control and punish the BVE population. ${ }^{80}$ During the Ombudsman's period of reference a sizeable proportion of cancellations were in fact set aside by the Administrative Appeals Tribunal (AAT). The Ombudsman's report found that between 29 June 2013 (when the powers commenced) and 9 October 2016, 322 BVEs held by IMAs were cancelled under section 116(1)(g) and regulation 2.43(1)(p). Of the cancellation decisions made by the Department under these laws, 55 decisions were set aside by the AAT and the former Migration Review Tribunal. ${ }^{81}$ The cancellation of asylum seekers BVEs is an example par excellence of crimmigration practices significantly exceeding both crime and immigration regulation, since even if charges are dropped, there is no right to simply apply for another bridging visa once the existing visa is cancelled. Instead, the Minister must exercise a non-compellable discretion to lift the bar and then to grant a further visa.

\section{Type, Occurrence and Source of Allegations}

In the FOI data, the 'type' of alleged breach is only categorised in a very general manner (listed in a column titled 'alleged breach') and further details about each allegation are not recorded. As such, it is difficult to know anything beyond the broad type of the allegation. The 'types' of allegation can be divided into two groups - those that reflect existing criminal offences and those that reflect behavioural

\footnotetext{
${ }^{79}$ In 18 instances no breach was found (4\%), while in 66 instances (13\%), the assessor decision was 'insufficient evidence'. In 68 instances (14\%), no assessor decision was recorded. The slight discrepancy in numbers reflects the fact that in some instances there was a BVE cancellation or non-renewal even though no breach was recorded, and so these are double counted for the purposes of outcomes.

${ }^{80}$ Neave 2016, pp. 11-14.

${ }^{81}$ Neave 2016, pp. 13.
} 
norms imposed by the Code of Behaviour and do not ostensible correspond with existing criminal laws. Despite the minimal detail in the allegations, they nonetheless raise serious concerns about the netwidening effect that the amorphous and ill-defined terms of the Code of Behaviour have had on the policing and surveillance of asylum seekers. The allegations of 'dishonesty' and 'harass/intimidate/bully' mirror the provisions of the Code of Behaviour which exceed the criminal law and recognisable criminal offences. Alongside these 'allegations', Code-related allegations types included:

- Threatening / verbally abusive behaviour

- Sexual contact - over 18

- Sexual contact - under 18

- Disturbance

- Public nuisance

- Self-harm

- Uncooperative to resolution of status

- Anti-social/ disruptive behaviour

As Methven and I have argued elsewhere, offences under the Code and its 'perverse preoccupation with the subject of manners [and behaviour] is consistent with colonial, civilising discourses' requiring racialised 'others' to learn from and adopt the customs of the new host state over their own cultures. ${ }^{82}$ Further, since most breaches of the Code resulted in counselling or a discussion with service providers, the disciplining effect of Code, even in the absence of a visa cancellation or other forms of penalty is clear.

The breach types that reflect existing criminal offences range from 'theft/larceny/shoplifting' and 'driving offences' to assault and aggravated sexual assault. However, outside of the breaches that appear to be related to the Code's expanded and undefined behavioural norms, the minor nature of many of the criminal charges or allegations that resulted in cancellation is of concern. The Ombudsman's Report addressed not only the erosion of the presumption of innocence where cancellation occurs on the basis of a charge alone, but also the lack of proportionality where decisions are made 'to cancel a visa under [regulation 2.43] in relation to charges that sit on the more minor end of the spectrum'. ${ }^{83}$ The Ombudsman also noted anecdotal reports that in some cases the department issued the [notice of intention to cancel] to the visa holder as they were leaving court having just been granted bail', noting that one of the factors in bail grants is whether unacceptable risk will be posed to the community. ${ }^{84}$

In terms of the occurrence rates of particular classes of breach or offence, driving offences made up over a quarter (28\% or 139/499) of all alleged breaches. Of the 138 allegations based on driving offences, 20 per cent of these led to BVE cancellation. These offences are not described beyond this categorisation. However, offences such as driving without a valid license or driving unregistered cars must be read in light of the criminogenic nature of BVE holders' limited access to work and income support. The flow-on effects or 'entrapment' caused by living without regular or adequate income include barriers to accessing public transport, licences, and valid vehicle insurance and registration.

The next highest incidence of alleged breaches were assault (14\%), followed by domestic violence $(10 \%)$ and drug offences $(5 \%)$. Once again, the severity of these offences is unclear but even in the absence of further detail, the allegation types raise at least two concerns. First, what processes are followed to investigate high level allegations like domestic violence where no visa cancellation action is taken or no corresponding criminal charges are laid. Second, for broadly categorised offences like

\footnotetext{
${ }^{82}$ Vogl and Methven 2015, p. 179.

${ }^{83}$ Neave 2016, p. 8.

${ }^{84}$ Neave 2016, p. 8 .
} 
driving offences, the charge may range from driving an unregistered vehicle to dangerous driving, raising the question of whether visa cancellation is taking place for minor infringements and if cancellation is a proportionate response? On this latter question, the Ombudsman Report noted that 'it appears that the department tends towards cancellation of a visa even if the charge is not serious'; and rightly queried whether a person charged, or even convicted, of minor matters 'such as shoplifting or a minor traffic offence' should be detained. ${ }^{85}$

The Code and bridging visa cancellation powers are clearly instruments for increased surveillance, heightened self-policing and day to day precarity for asylum seekers. This fact is also evident in the reporting patterns and source of allegations recorded in the FOI dataset. The column recording the source of allegations reveals that 61 per cent of allegations (301 out of 499) originated from the organisations providing the asylum seeker with resettlement services and assistance (SRSS providers). The next highest source was the 'National Allegation Assessment Team Dob-in Line', which was responsible for 9 per cent of allegations. 'Police' only accounted for 5 per cent of allegations, and 'case workers' accounted for another 3 per cent. ${ }^{86}$

The table clearly reveals the participation of charity and non-government and settlement organisations in the surveillance, policing and reporting of asylum seeker behaviour, and that these organisations are at the centre of the operation of both the Code and section $116(\mathrm{~g})$ cancellations. The statistics regarding the source of allegations reinforces Weber's account of the ever-expanding web of agents who police, surveil and report on asylum seeker and non-citizen populations - a network of policing and reporting much wider than networks of surveillance and law enforcement experienced by certain classes of citizens. ${ }^{87}$ Both the source of allegations and the type of 'alleged breach' warrant significant further investigation. This would include investigation into the status of reporting requirements in SRSS contracts, which are not publically available, and the approach of organisations to these obligations, as well as into the details of the 'top level' descriptions of breaches (such as driving offences and sexual contact), and outcomes in the criminal justice system of the charges that triggered visa cancellations.

There is clearly more work to be done and further data required, to interrogate both the data in the table, and the implications of breach allegations and visa cancellations. Indeed, one pressing, further question arising from this data is whether all those with visa cancellations are being re-detained, given the shrinking population of onshore asylum seekers currently being held in immigration detention and the increasing number of visa cancellations. An FOI on this exact question was made to the Department but at the time of writing the request had been refused on the basis that the Department held 'no current reports or systems' to exact the information. ${ }^{88} \mathrm{I}$ also note that the statistics recounted here are not gendered and do not reveal other conditions on BVEs, such as access to work rights or to the SRSS.

While this chapter does not address details about the management of BVE cancellations and consequences of these cancellations once they have been made, the Ombudsman's Report into the

\footnotetext{
${ }^{85}$ Neave 2016, p. 8.

${ }^{86}$ The nature of the case worker is not explained, so this could refer to an SRSS provider or other kind of worker. Note some 'sources' are difficult to identify without further information from the Department. For example, 'compliance' were responsible for six allegations.

87 Weber 2013.

${ }^{88}$ FOI Request FA 18/03/00501. Note that Louise Boon-Kuo has traced aspects of the gap between rhetoric regarding a 'universal visa system' and instances where the Government has permitted non-citizens 'to stay in the Australian community without a visa'. This included a period between 2014-15 where the Department stopped renewing bridging visas but advocates witnessed that simultaneously, those with expired BVEs were not being re-detained; see Boon-Kuo 2017, p. 131. Also, in Departmental reports on BVE holders in the Community, the Department has recorded 1815 people awaiting the grant of a further BVE. As noted in Refugee Council of Australia 2018d, 'This means that these people do not currently have lawful permission to stay in the community, and do not have current rights to work, study or access Medicare'.
} 
exercise of section $116(\mathrm{~g})$ shows that, due to gross delays and mismanagement of immigration detention, BVEs are not reissued (at the Minister's discretion) even where the charges which formed the basis for the cancellation were dropped. At the same time, BVE cancellations endure while criminal charges are on foot and so, 'due to delays in local court systems, people may have to wait months in detention before their charges can be heard by the courts', adding to the uncertainty they face ${ }^{89}$ While some crimmigration scholarship has noted the theoretically stronger protection of liberty under criminal law and process, the BVE holders in detention awaiting delayed criminal trials exist at the crossover of the worst excesses, mismanagement and injustices of both systems.

\section{Conclusion}

The adaptive nature of crimmigration control and its non-linear shifts makes living at the intersection of criminal and immigration laws, policies and discretions unpredictable, precarious and harmful. ${ }^{90}$ In thinking about further research in this area, it is worthwhile recalling one of the areas for future research identified by Gerard and Pickering back in 2013; namely the need for more empirical research to document the lived experience of crimmigration control and powers. ${ }^{91}$ Important research since that time has extended the frame of reference beyond state forms of control to asylum seekers' experience of and resistance to punitive policies; ${ }^{92}$ and as regimes of control intensify, further scholarship addressing these questions is urgent and necessary. As Gerard and Pickering observe, 'unless you address the resistance and coping mechanisms adopted by subjects, you will be oversimplifying the perception of irregular migrants as either "victims" of exploitation or "villains" who break the law'. ${ }^{93}$

This chapter has argued that in order to fully understand mandatory detention as a form of immigration control and deterrence of asylum seekers in Australia, closer attention needs to be paid to the regime of temporary, discretionary release from detention through BVEs and the subsequent regulation and policing of bridging visa holders living in the community. The release of onshore asylum seekers from Australian-based detention centres on bridging visas is a practice that is more than ancillary to immigration detention - it is central to Government strategies of punishment and deterrence of asylum seekers. Further, the vast discretions that govern release from detention and the socio-economic marginalisation of the bridging visa population must be read alongside the heightened use of BVE cancellation powers and threat of re-detention. New mechanisms for policing and surveillance as a result of the Asylum Seeker Code of Behaviour and existing cancellation powers, which allow for redetention on the basis of behavioural norms, criminal convictions and charges, exceed the operation of the criminal law and form part of an expanding regime for the surveillance, control and punishment of asylum seekers living in the community.

\footnotetext{
${ }^{89}$ Neave 2016, p. 20.

90 Sklansky 2012.

${ }^{91}$ Gerard and Pickering 2013.

${ }^{92}$ Fleay et al. 2013; Hartley and Fleay 2017.

${ }^{93}$ Gerard and Pickering 2013; see also Anderson and Ruhs 2010.
} 


\section{References}

Aas KF (2014) Bordered penality: Precarious membership and abnormal justice. Punishm Soc 16(5):520-541. doi: $10.1177 / 1462474514548807$.

Anderson B, Ruhs M (2010) Researching illegality and labour migration. Popul Space Place 16(3):175-179. doi: 10.1002/psp.594.

Billings P (2015) Whither indefinite immigration detention in Australia?: Rethinking legal constraints on the detention of non-citizens. Univ N.S.W. Law J 38(4):1386-1420.

Boon-Kuo L (2017) Policing Undocumented Migrants: Law, Violence and Responsibility. Routledge, London.

Bosworth M (2008) Border Control and the Limits of the Sovereign State. Soc Leg Stud 17(2):199-215. doi: $10.1177 / 0964663908089611$.

Bosworth M, Guild M (2008) Governing Through Migration ControlSecurity and Citizenship in Britain. Br J Criminol 48(6):703-719. doi: 10.1093/bjc/azn059.

Bowen C (2011) Media Release: Bridging Visas to be Issued for Boat Arrivals (Minister for Immigration and Citizenship). Parliament of Australia.

http://parlinfo.aph.gov.au/parlInfo/search/display/display.w3p;query=Id\%3A\%22media\%2Fpressrel\%2 F1251281\%22. Accessed 11 Feb 2019.

Cohen H (2013) No advantage: asylum seekers in community limbo. Background Briefing (ABC Radio National, 4 June 2013). https://www.abc.net.au/radionational/programs/backgroundbriefing/2013-0609/4732682. Accessed 13 Nov 2018.

Dauvergne C (2008) Making People Illegal: What Globalization Means for Migration and Law. Cambridge University Press, Cambridge.

De Genova NP (2002) Migrant "Illegality” and Deportability in Everyday Life. Annu Rev Anthropol 31(1):419-447. doi: 10.1146/annurev.anthro.31.040402.085432.

Department of Home Affairs (n.d.) Immigration Detention in Australia. https://www.homeaffairs.gov.au/about/immigration-detention-in-australia/detention-in-australia. Accessed 5 Jun 2018.

Department of Home Affairs (2018) Key Visa Cancellation Statistics. https://www.homeaffairs.gov.au/researchand-statistics/statistics/visa-statistics/visa-cancellation. Accessed 11 Nov 2018.

Department of Immigration and Border Protection (n.d.) Procedures Advice Manual 3: Migration Act Detention Services Manual. Commonwealth of Australia, Canberra.

Department of Immigration and Border Protection (2013) Code of Behaviour for Subclass 050 Bridging (General) Visa Holders, Government of Australia. Commonwealth of Australia, Canberra.

Department of Immigration and Border Protection (2014) Annual Report 2013-14. Commonwealth of Australia, Canberra. https://archive.homeaffairs.gov.au/ReportsandPublications/Documents/annualreports/DIBP_AR_2013-14.pdf. Accessed 11 Feb 2019.

Department of Immigration and Border Protection (2015) Annual Report 2014-15. Commonwealth of Australia, Canberra. https://archive.homeaffairs.gov.au/about/reports-publications/reports/annual/immigration2014-15. Accessed 11 Feb 2019.

Department of Immigration and Border Protection (2016) Annual Report 2015-16. Commonwealth of Australia, Canberra. https://archive.homeaffairs.gov.au/about/reports-publications/reports/annual/annual-report2015-16. Accessed 11 Feb 2019. 
Dutton P (2017) Media Release: 1000 Days of Strong and Secure Borders. http://minister.homeaffairs.gov.au/peterdutton/Pages/1000-days-strong-secure-borders.aspx. Accessed 11 Feb 2019.

Fleay C, Hartley L, Kenny MA (2013) Refugees and asylum seekers living in the Australian community: the importance of work rights and employment support. Aus J Soc Issues 48(4):473-493. doi: 10.1002/j.1839-4655.2013.tb00294.x.

Garland D (2003) The Culture of Control: Crime and Social Order in Contemporary Society. Oxford University Press, Oxford.

Grewcock M (2005) Slipping through the Net - Some Thoughts on the Cornelia Rau and Vivian Alvarez Inquiry. Curr Issues Crim Justice 17(2):284-290.

Grewcock M (2014) Australian border policing: regional 'solutions' and neocolonialism. Race Class 55(3):7178. doi: 10.1177/0306396813509197.

Hartley L and Fleay C (2017) "We are Like Animals": Negotiating Dehumanising Experiences of AsylumSeeker Policies in the Australian Community. Refugee Surv Q 36(4):45-63. doi: 10.1093/rsq/hdx010.

Hekmat A (2018) Asylum Seekers’ Benefits Cut by Home Affairs. The Saturday Paper. https://www.thesaturdaypaper.com.au/news/politics/2018/04/14/asylum-seekers-benefits-cut-homeaffairs/15236280006087. Accessed 11 Feb 2019.

Karlsen E (2016) Australia's offshore processing of asylum seekers in Nauru and PNG: a quick guide to statistics and resources. In: Parliamentary Library. Parliament of Australia. https://www.aph.gov.au/About_Parliament/Parliamentary_Departments/Parliamentary_Library/pubs/rp /rp1617/Quick_Guides/Offshore. Accessed 13 Nov 2018.

Koleth E (2012) Asylum Seekers: An Update. Parliament of NSW Briefing Paper, 1/2012. Parliament of New South Wales, Sydney. https://www.parliament.nsw.gov.au/researchpapers/Pages/asylum-seekers--anupdate.aspx.

Laughland O (2014) Angus Campbell warns asylum seekers not to travel to Australia by boat. The Guardian. https://www.theguardian.com/world/2014/apr/11/angus-campbell-stars-in-videos-warning-asylumseekers-not-to-travel-by-boat. Accessed 13 Nov 2018.

McElrath S, Mahadeo R, Suh S (2014) "Crimmigration," With Tanya Golash-Boza, Ryan King, and Yolanda Vázquez. The Society Pages. https://thesocietypages.org/roundtables/crimmigration/. Accessed 11 Feb 2019.

Markus A, Taylor J (2006) No Work, No Income, No Medicare - the Bridging Visa E Regime. People Place 14(1):43.

Martin LL, Mitchelson ML (2009) Geographies of Detention and Imprisonment: Interrogating Spatial Practices of Confinement, Discipline, Law, and State Power. Geogr Compass 3(1):459-477. doi: 10.1111/j.17498198.2008.00196.x.

Migration Act 1958 (Cth).

Migration Amendment (Detention Arrangements) Act 2005 (Cth).

Migration Amendment (Subclass 050 and Subclass 051 Visas) Regulation 2013 (Cth).

Migration Regulations 1994 (Cth).

Minister for Immigration and Border Protection (2014) Direction No 63: Bridging E Visas — Cancellation Under Section 116(1)(g) - Regulation 2.43(1)(p)-(q). 
Mountz A (2010) Seeking Asylum: Human Smuggling and Bureaucracy at the Border. University of Minnesota Press, Minneapolis.

Mountz A, Coddington K, Catania RT, et al. (2012) Conceptualizing detention: Mobility, containment, bordering, and exclusion. Prog Hum Geogr 37(4):522-541. doi: 10.1177/0309132512460903.

Neave C (2016) The Administration of People Who Have Had Their Bridging Visa Cancelled Due to Criminal Charges or Convictions and are Held in Immigration Detention. Commonwealth Ombudsman Report, 7. Commonwealth Ombudsman, Canberra. http://www.ombudsman.gov.au/_data/assets/pdf_file/0026/42596/December-2016_Own-motioninvestigation-into-people-who-have-their-Bridging-visa-cancelled-following-criminal-charges.pdf.

Nethery A (2012) Separate and invisible: a carceral history of Australian islands. Shima 6(2):85-98.

Opeskin B (2012) Managing International Migration in Australia: Human Rights and the 'Last Major Redoubt of Unfettered National Sovereignty’. Int Migr Rev 46(3):551-585.

Phillips J (2017) Immigration Detention in Australia: A Quick Guide to the Statistics. In: Parliamentary Library. Parliament of Australia. https://www.aph.gov.au/About_Parliament/Parliamentary_Departments/Parliamentary_Library/pubs/rp /rp1617/Quick_Guides/ImmigrationDetention. Accessed 11 Feb 2019.

Pickering S, Gerard A (2013) Crimmigration: Criminal Justice, Refugee Protection and the Securitisation of Migration. In: Arrigo B, Bersot H (eds) The Routledge Handbook of International Crime and Justice Studies, 1st edn. Routledge, Abingdon.

Pickering S, Lambert C (2002) Deterrence: Australia’s Refugee Policy. Curr Issues Crim Justice 14(1):67-86.

Pickering S, Weber L (2014) New Deterrence Scripts in Australia's Rejuvenated Offshore Detention Regime for Asylum Seekers. Law Soc Inq 39(4): 1006-1026. doi: 10.1111/1si.12088.

Refugee Council of Australia (2018a) Detention statistics for Australia. https://www.refugeecouncil.org.au/getfacts/statistics/aust/asylum-stats/detention-australia-statistics/. Accessed 11 Nov 2018.

Refugee Council of Australia (2018b) Starving Them Out: How our Government is making people seeking asylum destitute. https://www.refugeecouncil.org.au/starving-them-out/. Accessed 11 Feb 2019.

Refugee Council of Australia (2018c) With empty hands: How the Australian Government is forcing people seeking asylum into destitution. https://www.refugeecouncil.org.au/with-empty-hands-destitution/. Accessed 11 Feb 2019.

Refugee Council of Australia (2018d) Statistics on people seeking asylum in the community. https://www.refugeecouncil.org.au/asylum-community/2/. Accessed 11 Feb 2019.

Silverman SJ, Massa E (2012) Why Immigration Detention is Unique. Popul Space Place 18(6): 677-686. doi: $10.1002 /$ psp. 1720 .

Silverman SJ, Nethery A (2015) Understanding immigration detention and its human impact. In: Silverman SJ, Nethery A (eds) Immigration Detention: The Migration of a Policy. Routledge, New York.

Sklansky DA (2012) Crime, Immigration, and Ad hoc Instrumentalism. New Crim Law Rev Intl Interdiscip J 15(2):157-223. doi: 10.1525/nclr.2012.15.2.157.

Sudbury J (2005) Global Lockdown: Race, Gender, and the Prison-Industrial Complex. Routledge, New York.

Vázquez Y (2015) Constructing Crimmigration: Latino Subordination in a Post-Racial World. Immigr Natly Law Rev 36:713. 
Vecchio F, Gerard A (2018) Entrapping Asylum Seekers: Social, Legal and Economic Precariousness. Springer, New York.

Vogl A, Methven E (2015) We Will Decide Who Comes to This Country, and How They Behave: A Critical Reading of the Asylum Seeker Code of Behaviour. Alt Law J 40(3):175.

Weber L (2013) Policing Non-Citizens. Routledge, London.

Welch M (2012) The Sonics of Crimmigration in AustraliaWall of Noise and Quiet Manoeuvring. Br J Criminol 52(2): 324-344. doi: 10.1093/bjc/azr068. 